\title{
Less intensified grazing management with growing fattening bulls
}

\author{
Francisco Dieguez CAMERONI ${ }^{\mathrm{a}}$, Jean-Luc HornicK ${ }^{\mathrm{a}}$, \\ Jean-François CABARAUX ${ }^{\mathrm{a}}$, Louis ISTASSE ${ }^{\mathrm{a}}$, Isabelle DUFRASNE ${ }^{\mathrm{b} *}$ \\ a Nutrition Unit, Veterinary Faculty, University of Liege, Belgium \\ ${ }^{\mathrm{b}}$ Experimental Station, Veterinary Faculty, University of Liege, Belgium
}

(Received 22 October 2004 - Accepted 6 January 2006)

\begin{abstract}
Animal performance, composition and quality of meat from Belgian Blue bulls either fattened indoors (FI) or finished indoors after a previous grazing period were studied during six years. During the grazing period, three intensification managements were tested on a permanent pasture conducted as set stocking. The intensification levels were either high (HN: $140 \mathrm{~kg} \mathrm{~N} \cdot \mathrm{ha}^{-1}$ with 6 bulls $\cdot h \mathrm{a}^{-1}$ ) or moderate with a 33\% reduction of nitrogen fertilisation but with the same stocking rate (MN: $93 \mathrm{~kg} \mathrm{~N} \cdot \mathrm{ha}^{-1}, 6$ bulls $\cdot \mathrm{ha}^{-1}$ ) or low with no nitrogen fertiliser but with a reduced stocking rate $\left(\mathrm{ON}, 4\right.$ bulls $\left.\cdot \mathrm{ha}^{-1}\right)$. The levels of intensification did not affect sward characteristics and chemical composition of the grass. The apparent nitrogen efficiency per ha was larger in the ON plot than in the $\mathrm{HN}$ and MN plots (26 vs. 14\%). The average daily gain of bulls during the grazing season was similar in the three groups at $1.0 \mathrm{~kg} \cdot \mathrm{d}^{-1}$. The bulls from the FI group were characterised by average daily gains significantly higher than the bulls which were previously grazed and then finished indoors $\left(1.5 \mathrm{vs} .1 .2 \mathrm{~kg} \cdot \mathrm{d}^{-1} ; P<0.01\right)$. The slaughter weight, the carcass composition, the dressing percentage and most of the meat quality parameters were similar between the treatment groups. The inclusion of a grazing period in the fattening system produced a meat which was darker (lower $\mathrm{L}^{*}, P<0.01$ ), more red (higher a*, $P<0.05$ ) and had a higher content of linolenic acid $(\mathrm{C} 18: 3 \mathrm{n}-3)$ than that of the animals fattened indoors.
\end{abstract}

fattening / bulls / grazing / nitrogen fertiliser / stocking rate

Résumé - Désintensification de la conduite de prairies pâturées par de jeunes taurillons. Les performances zootechniques, la composition et la qualité de la viande de taurillons Blanc Bleu belge engraissés uniquement en stabulation (FI) ou finis en stabulation après une période de pâturage ont été étudiées pendant six années. Pendant la période de pâturage, trois niveaux d'intensification ont été testés dans une prairie permanente. Le système de pâturage continu a été employé. Les niveaux d'intensification ont été soit élevé ( $\mathrm{HN}: 140 \mathrm{~kg} \mathrm{~N} \cdot h^{-1} ; 6$ taureaux$\left.\cdot \mathrm{ha}^{-1}\right)$, soit modéré avec une réduction de $33 \%$ de la fertilisation azotée mais avec le même chargement (MN : $93 \mathrm{~kg} \mathrm{~N} \cdot \mathrm{ha}^{-1}$; 6 taureaux $\left.\cdot h^{-1}\right)$, soit faible sans engrais azoté et avec un chargement réduit $\left(\mathrm{ON}: 4\right.$ taureaux $\left.\cdot \mathrm{ha}^{-1}\right)$. Les traitements n'ont pas affecté les mesures phytotechniques (hauteur de l'herbe, pourcentage de refus) ni les contenus en matière azotée totale et en fibres brutes de l'herbe. L'efficience d'utilisation d'azote à l'hectare a été plus élevée dans le lot ON par rapport aux lots HN et MN (26 vs. 14 \%). Le

\footnotetext{
* Corresponding author: Isabelle.Dufrasne@ulg.ac.be
} 
gain quotidien moyen des taureaux pendant la période de pâturage a été identique dans les trois lots $\left(1 \mathrm{~kg} \cdot \mathrm{j}^{-1}\right)$. Les taurillons du groupe FI ont présenté des gains quotidiens moyens significativement plus élevés que ceux des taurillons ayant séjourné en prairie et finis en stabulation $\left(1,5 \mathrm{vs} .1,2 \mathrm{~kg} \cdot \mathrm{j}^{-1}\right.$; $P<0,01)$. Le poids d'abattage, la composition de carcasse ainsi que le rendement à l'abattage et les paramètres de qualité de viande ont été semblables entre les traitements. L'inclusion d'une période de pâturage a produit une viande plus foncée et rouge par rapport au lot FI. Les teneurs en C18:3 ont été plus élevées $(P<0,05)$ pour les taurillons du lot HN par rapport à celles du lot FI.

\section{engraissement / taurillons / pâturage / fumure azotée / chargement}

\section{INTRODUCTION}

In Belgium, about one third of beef meat is produced by the fattening of young bulls. Most of them are from the Belgian Blue breed [29]. This breed is characterised by large muscular development, a high dressing percentage and a high proportion of first class cuts [23]. The fattening period starts when the animal live weight is about $300 \mathrm{~kg}$. Usually the young growing fattening bulls are maintained indoors but a grazing period could be set up in the growingfattening scheme, e.g., a first grazing season as calves [11], a first indoor period as young stock, a second grazing season starting at $300-350 \mathrm{~kg}$ and a final finishing period indoors [20].

In the past, the intensification rate in the management of grazing areas, determined by the level of nitrogen fertilisation and the stocking rate, was high in order to obtain the maximal yield per hectare. Nitrogen fertiliser induced important effects on grass composition, animal performances and nitrogen losses. In the context of environmental policy, it is of importance to reduce nitrogen excretions by animals along with nitrogen fertilisation and the risk of leaching. A drastic reduction in nitrogen fertilisation up to zero may therefore be suggested. The stocking rate must be adapted in order to maintain high individual performances. The consumer's attitude towards beef meat has also changed, extensive production systems being associated with natural products. Furthermore, ethical and nutritional factors encourage consumption of products from farms in which production systems are environmentally friendly [54].
The inclusion of a grazing period before indoor finishing can influence meat characteristics, such as colour, flavour and fatty acid composition $[43,55]$. One objective in beef meat production is to provide consumers with high quality products. Recently attention has been focussed on the use of a more natural production system in order to improve the image of meat for the public. So the inclusion of a grazing period in the overall management appears to be more natural and therefore more acceptable.

The present paper reports the impacts of two strategies on grass characteristics and on young grazing bull performance: a mild reduction in nitrogen fertiliser without a reduction of stocking rate on the one hand and, on the other hand, a reduction in stocking rate with no nitrogen application. The animal performance and the meat characteristics of these bulls previously grazed before an indoor finishing period were also compared with performances of bulls fattened indoors.

\section{MATERIALS AND METHODS}

\subsection{Animals, grazing and fattening management}

One hundred ninety-two Belgian Blue bulls were used in a study over a 6-year period. They were divided each year into 4 groups of 8 animals on the basis of their live weight. One group was fattened indoors (FI). The three other groups were grazed on a pasture located $150 \mathrm{~m}$ above 
Table I. Nitrogen fertiliser, stocking rate and live weights of Belgian blue bulls grazed over a six years experiment.

\begin{tabular}{lccc}
\hline & \multicolumn{3}{c}{ Treatments } \\
\cline { 2 - 4 } & HN & MN & ON \\
\hline Stocking rate (bulls $\left.\cdot \mathrm{ha}^{-1}\right)$ & 6 & 6 & 4 \\
Fertilisation $\left(\mathrm{kg} \mathrm{N} \cdot \mathrm{ha}^{-1}\right)$ & 140 & 93 & 0 \\
Initial live weight $(\mathrm{kg})$ & 293 & 294 & 293 \\
\hline
\end{tabular}

sea level. The pasture, previously used for crops and cereal production was seeded in September with $45 \mathrm{~kg} \cdot \mathrm{ha}^{-1}$ of Lolium perenne $(70 \%)$, Festuca pratensis $(10 \%)$, Phleum pratense (10\%), Trifolium repens $(10 \%)$. It was fertilised with 63 units of $P$ and 63 units of $\mathrm{K}$ per ha in March. Grazing started in the beginning of May and ended at the end of September after an average grazing period of 145 days. The spring fertilisation and trial was repeated over six consecutive years. The set stocking system was used. A first group was grazed at a high stocking rate and a high nitrogen fertiliser level (high nitrogen: HN). The second group was managed in a grazing system with a high stocking rate but with a nitrogen fertiliser level reduced by $33 \%$ (medium nitrogen: MN). The third group was grazed at a stocking rate reduced by $33 \%$ compared to groups 1 and 2 and no nitrogen fertiliser was applied (ON) (Tab. I). The area of the plots was 1.33 ha for groups $\mathrm{HN}$ and $\mathrm{MN}$ and 2.0 ha for group $\mathrm{ON}$ so that the stocking rate was 6,6 and 4 bulls per ha respectively. The animals were offered a mixture of $50 \%$ dry sugar beet pulp and $50 \%$ rolled barley at a mean rate of $1 \mathrm{~kg} \cdot$ animal $^{-1} \cdot \mathrm{day}^{-1}$. The amount was increased in all grazing groups during some period when grass availability was insufficient to permit animals to remain at pasture. Over the 6-year period, the amount varied from 0.9 to $1.2 \mathrm{~kg} \cdot \mathrm{animal}^{-1} \cdot \mathrm{day}^{-1}$ over the grazing season.

Ammonium nitrate - $27 \% \mathrm{~N}$ - was used as nitrogen fertiliser and spread in different fractions at the same dates in plots $\mathrm{HN}$ and
MN. Rainfall and average daily temperature were recorded in a station from the Royal Institute for Meteorological Weather Forecast located close to the pasture. After the grazing season, the animals in their respective groups were housed for finishing in a pen partially bedded with straw as the FI group.

All groups received a fattening diet made of $41.5 \%$ of dried sugar beet pulp, 9\% barley, $9 \%$ maize, $9 \%$ spelt, $9 \%$ middlings, 9\% soya bean meal, 9\% linseed meal, $4 \%$ molasses and $0.5 \%$ minerals and vitamins. A transition period of 10 days was managed during which the concentrate diet was gradually increased to reach ad libitum feeding. The animals were slaughtered according to the fattening state estimated by palpation of the tail head, loin and rib area. This selection was based on an individual animal. The degree of fatness required for the slaughter was approximately 4.5 (scale from 0 , very lean, to 5 , very fat).

\subsection{Measurements}

\subsubsection{Pasture}

Grass samples were obtained every two weeks with scissors at $1 \mathrm{~cm}$ from the ground, a sample corresponding to 1015 handfuls taken at random. The chemical composition of grass was determined on the dried samples according to official procedures [3]. The solubility of the nitrogen fractions was measured by extraction in an artificial saliva and precipitation with trichloroacetic acid. Grass height was recorded in the presence of the animals every two weeks with a $30 \times 30 \mathrm{~cm}$ aluminium settling plate instrument with a pressure of $2 \mathrm{~kg} \cdot \mathrm{m}^{-2}$; 100 measures being obtained per ha. Herbage refusals were estimated every two weeks from the measurements of grass height: refusals were visualised and noted by the operator during the measurements. Botanical composition was determined during the final year 
by a technique adapted from the method of the frequencies [2]. Grass yield was not recorded in the present trial but, for calculation of nitrogen balance, data were obtained from neighbouring pastures grazed by dairy cows and managed in a similar manner [10]. In these pastures, grass yield was estimated for each of the systems (HN, $\mathrm{MN}$ and $\mathrm{ON}$ ) in two $5 \mathrm{~m}^{2}$ plots out of the reach of the cattle, by recording grass production cut alternatively every two weeks with a mowing machine at $4 \mathrm{~cm}$ height.

\subsubsection{Animals}

At the beginning of grazing, the animals weighed on average $294 \mathrm{~kg}$ and were 9-10 months old. Live weights were recorded every 28 days and before slaughter (final weight). They were also weighed at slaughter (slaughter weight). The total live weight gain was calculated and expressed per ha. Daily concentrate intake was recorded per group and the feed conversion ratio was calculated. The number of grazing days per ha was calculated from the stocking rate and the length of the grazing season.

At slaughter, hot carcass weight was recorded and $\mathrm{pH}$ and temperature were measured in the Longissimus thoracis muscle on both sides 1, 2, 4 and 48 hours postmortem using a Portamess 751 knick pH-meter (Knick GmbH \& Co, Berlin, Germany) with an Ingold "penetration" pH-electrode (IngoldAG, Urdorf, Switzerland). Two days after slaughter, the 8th rib was removed from the carcass. It was dissected to separate lean meat, fat and connective tissue and bones in order to assess carcass composition [22]. A pair of $2.5 \mathrm{~cm}$ thick cuts was sampled from the Longissiumus thoracis. In the first one and after $1.5 \mathrm{~h}$ blooming time, the colour was objectively measured with a Hunterlab Labscan II device according to CIE L* a* b*. There were 5 measures per sample dis- tributed on the surface. The second $2.5 \mathrm{~cm}$ - thick cut was heated in an open plastic bag in water both for $50 \mathrm{~min}$ at $75^{\circ} \mathrm{C}$. After heating, the bags were cooled in cold tap water to room temperature. They were then drained and the cuts were mapped gently dry with paper tissue. The difference between raw and heated weights was recorded as cooking loss and expressed as a proportion of raw weight. The tenderness expressed by its opposite, toughness, was estimated by the measurement of the Warner-Bratzler peak shear force (WBPSF) with a Lloyd LD5K testing machine (Lloyd Instruments Ltd, Fareham, England) perpendicular to the muscular fibres direction on ten $1.25 \mathrm{~cm}$ - diameter cores, obtained from the heated cuts. Another sample of Longissimus thoracis was freeze-dried and ground for chemical composition determination. The dry matter, ash, ether extract and crude protein of meat samples were determined according to official procedures [3]. For the bulls of groups FI and HN during the second year, the lipids from intramuscular fat samples were extracted and saponified as described by Ter Meulen et al. [51] and the intramuscular fatty acid composition was determined by gas chromatography using a Chrompack CP 9001 chromatograph (Middleburg, The Netherlands) fitted with a capillary column DB-225 (J\&W, Folsom, USA). C17:0 was used as the internal standard.

\subsection{Statistical analysis and assessment of nitrogen balance}

The statistical analysis was carried out using the "general linear model" procedure of MINITAB [38]. The effects of treatment and year were considered as fixed. For measures performed on individual animals, the following model was used:

Yij $=\mu+\alpha_{i}+\beta_{j}+\alpha \beta_{i j}+\varepsilon_{i j n}$ where $\mu=$ overall mean, $\alpha_{i}=$ effect of treatment, 
$\beta_{j}=$ effect of year, $\alpha \beta_{i j}=$ interaction between treatment and year effects, and $\varepsilon_{i j n}=$ random residual effects associated with the n observations $(\sim \mathrm{N}[0, \sigma])$.

The model Yij $=\mu+\alpha_{i}+\beta_{j}+\varepsilon_{i j n}$ was used for measures performed on groups used as an experimental unit or production data expressed on a per ha basis. When differences were observed between treatments, the comparisons were made using the method of orthogonal contrasts [5], in order to analyse the effect of the presence or the absence of nitrogen fertiliser (ON vs. $\mathrm{HN}$ and $\mathrm{MN}$ ) and the effect of the nitrogen fertiliser level (HN vs. MN) at a similar stocking rate.

The fatty acids data were compared by the Student t-test.

In the calculation of nitrogen balance, the nitrogen input from rainfall was estimated at $10 \mathrm{~kg} \mathrm{~N} \cdot \mathrm{ha}^{-1} \cdot \mathrm{year}^{-1}$ according to the figures reported by Simpson and Stobbs [48] and Decau et al. [7]. Nitrogen fixation by the legumes was calculated using the relationship proposed by Farruggia et al. [15]:

Nitrogen fixed by legumes $\left(\mathrm{kg} \cdot \mathrm{ha}^{-1}\right)=$ Biomass produced by the pasture $(\mathrm{kg}$ $\left.\mathrm{DM} \cdot \mathrm{ha}^{-1}\right) \times \mathrm{PC}(\%) \times \mathrm{NPC}(\%) \times \mathrm{fix}-$ ation $(\%)$ in which $\mathrm{PC}$ was the percentage of clover, NPC the nitrogen content in the clover (0.035) and fixation the average nitrogen fixation by clover $(0.90)$.

Nitrogen fixed as meat by the grazing animals was calculated as the total live weight gain by the animals during the whole grazing season $\left(\mathrm{kg} \cdot \mathrm{ha}^{-1} \cdot \mathrm{year}^{-1}\right) \times$ the amount of nitrogen fixed in one $\mathrm{kg}$ live weight, 0.032 [6]. The nitrogen content of the concentrate was estimated using published tables [28]. The apparent efficiency of nitrogen utilisation in a grazing system was calculated as the ratio between nitrogen output and total nitrogen input to the system [33].

\section{RESULTS}

\subsection{Grass yield and characteristics}

Grass yield was 11.7, 11.5 and 9.6 tons of dry matter per ha in the $\mathrm{HN}, \mathrm{MN}$ and $\mathrm{ON}$ groups respectively (Tab. II). The percentage of legumes was the lowest in the HN group while the percentage of gramineae was the highest. The percentage of undefined plants was similar in the three treatments.

Grass height was the highest - although the difference was not significant - in the ON group as compared with the two other treatments ( 8.6 vs. $6.6 \mathrm{~cm} ; P>0.05)$. The refusal percentage was slightly larger in the $\mathrm{MN}$ and $\mathrm{ON}$ groups (12.7 vs. $10.4 \%$ ). The ADF, CP and nitrogen fraction contents were not significantly different. The mineral contents of grass varied from one year to another and there were no interactions between years and treatments. The phosphorus, potassium and magnesium contents did not vary between the treatments. The sodium content was significantly higher in the HN group while calcium was the highest in the ON group.

\subsection{Animal performance at grass and nitrogen balance}

The average daily gain during the grazing season was similar in the three groups (1 kg.d ${ }^{-1} ; P>0.05$ ) (Tab. III). The live weight gains per ha were larger in the $\mathrm{HN}$ and $\mathrm{MN}$ groups than in the $\mathrm{ON}$ group $\left(899 \mathrm{~kg} \cdot \mathrm{ha}^{-1}\right.$ in the plots with nitrogen fertiliser and $629 \mathrm{~kg} \cdot \mathrm{ha}^{-1}$ in the ON group; $P<0.01)$. The concentrate intake during the grazing season was $157 \mathrm{~kg} \cdot \mathrm{bull}^{-1}$. The number of grazing days was significantly higher in $\mathrm{MN}$ and $\mathrm{HN}$ than in the $\mathrm{ON}$ group (870 vs. $580 \mathrm{~d} \cdot \mathrm{ha}^{-1}: P<0.001$ )

The nitrogen outputs as meat were lower in the ON group as compared with the two other groups (20 vs. $28 \mathrm{~kg}$ $\mathrm{N} \cdot \mathrm{ha}^{-1} \cdot$ year $^{-1}$ ) (Tab. IV). The nitrogen balance was positive in the three groups with 
Table II. Yield, botanical composition, sward characteristics and grass chemical composition of plots fertilised at $140(\mathrm{HN}), 93(\mathrm{MN})$ or $0(\mathrm{ON}) \mathrm{kg} \mathrm{N} \cdot \mathrm{ha}^{-1}$ and grazed at a stocking rate of 6,6 or 4 Belgian Blue bulls $\cdot h a^{-1}$.

\begin{tabular}{|c|c|c|c|c|c|}
\hline & \multicolumn{5}{|c|}{ Treatment } \\
\hline & $\mathrm{HN}$ & MN & $\mathrm{ON}$ & RSD & $P$ \\
\hline Yield $\left(1000 \mathrm{~kg}\right.$ DM·ha $\left.{ }^{-1}\right)$ & 11.7 & 11.5 & 9.6 & - & NS \\
\hline Legumes (\%) & 15.2 & 17.7 & 17.8 & - & NS \\
\hline Gramineae $(\%)$ & 69.3 & 66.9 & 66.3 & - & NS \\
\hline Others $(\%)$ & 15.5 & 15.4 & 15.9 & - & NS \\
\hline Grass height (cm) & 6.2 & 7.1 & 8.6 & 2.3 & NS \\
\hline Refusal percentage (\%) & 10.4 & 12.7 & 12.6 & 8.1 & NS \\
\hline \multicolumn{6}{|l|}{ Chemical composition: } \\
\hline Dry matter $(\%)$ & 17.1 & 16.8 & 16.5 & 5.1 & NS \\
\hline Ashes (\% DM) & 11.7 & 11.6 & 11.3 & 1.0 & NS \\
\hline $\mathrm{ADF}(\% \mathrm{DM})$ & 22.9 & 23.0 & 22.6 & 1.3 & NS \\
\hline Crude protein (\% DM) & 21.0 & 21.0 & 20.3 & 3.3 & NS \\
\hline Sol N $(\%$ tot $N)$ & 31.4 & 32.0 & 32.7 & 6.2 & NS \\
\hline Sol non $\operatorname{prot} \mathrm{N}(\%$ tot $\mathrm{N})$ & 22.9 & 22.7 & 23.3 & 4.6 & NS \\
\hline Sol prot $N(\%$ tot $N)$ & 8.4 & 9.4 & 9.4 & 3.0 & NS \\
\hline $\mathrm{NH}_{3}(\%$ tot $\mathrm{N})$ & 1.5 & 1.5 & 1.4 & 0.3 & NS \\
\hline $\mathrm{NO}_{3}(\%$ tot $\mathrm{N})$ & 8.7 & 7.2 & 6.8 & 2.8 & NS \\
\hline \multicolumn{6}{|l|}{ Minerals : } \\
\hline $\mathrm{Ca}\left(\mathrm{g} \cdot \mathrm{kg}^{-1} \mathrm{DM}\right)$ & $7.24 \mathrm{a}$ & $7.35 \mathrm{a}$ & $8.37 \mathrm{~b}$ & 1.17 & $*$ \\
\hline $\mathrm{P}\left(\mathrm{g} \cdot \mathrm{kg}^{-1} \mathrm{DM}\right)$ & 4.40 & 4.28 & 4.11 & 0.49 & NS \\
\hline $\mathrm{Na}\left(\mathrm{g} \cdot \mathrm{kg}^{-1} \mathrm{DM}\right)$ & $0.79 \mathrm{a}$ & $0.67 \mathrm{~b}$ & $0.62 \mathrm{~b}$ & 0.16 & $*$ \\
\hline $\mathrm{Mg}\left(\mathrm{g} \cdot \mathrm{kg}^{-1} \mathrm{DM}\right)$ & 2.03 & 1.99 & 1.99 & 0.21 & NS \\
\hline $\mathrm{K}\left(\mathrm{g} \cdot \mathrm{kg}^{-1} \mathrm{DM}\right)$ & 36.86 & 37.10 & 34.19 & 4.35 & NS \\
\hline
\end{tabular}

ADF: acid detergent fibre; Sol N: soluble nitrogen; Sol non prot N: soluble non protein nitrogen; Sol prot $\mathrm{N}$ : soluble protein nitrogen; $\mathrm{NH}_{3}$ : ammonia; $\mathrm{NO}_{3}$ : nitrates.

Means within a row with different superscripts differ significantly at $P<0.05$.

the ON group being much lower $(58,155$ and $192 \mathrm{~kg} \mathrm{~N} \cdot \mathrm{ha}^{-1} \cdot \mathrm{year}^{-1}$ in the $\mathrm{ON}, \mathrm{MN}$ and $\mathrm{HN}$ groups, respectively). The apparent efficiency of nitrogen utilisation was greatly improved in the ON plot as compared with the plots with nitrogen fertiliser $(26 \%$ vs. $14 \%)$.

\subsection{Finishing performance, slaughter, meat composition and quality}

The FI bulls started the fattening at the beginning of the grazing season. Their initial live weight was $312 \mathrm{~kg}$. The duration of the indoor finishing (96 days) for the bulls previously grazed was similar between the groups and was shorter $(P<0.05)$ than that in the FI group (163 days) (Tab. V). The duration was, however, extended when both periods grazing and finishing - were considered (241 vs. 163 days). Figure 1 gives the evolution of the live weight. During the grazing period a more even growth curve was observed with the FI group while a period of reduced growth was recorded at the end of grazing and the beginning of 
Table III. Performance of young bulls grazing pastures fertilised at $140(\mathrm{HN}), 93$ (MN) or 0 (ON) kg $\mathrm{N} \cdot \mathrm{ha}^{-1}$ and grazed at a stocking rate of 6,6 or 4 Belgian Blue bulls $\cdot \mathrm{ha}^{-1}$.

\begin{tabular}{lccccc}
\hline & \multicolumn{5}{c}{ Treatments } \\
\cline { 2 - 6 } & HN & MN & ON & RSD & $P$ \\
\hline Concentrate intake $\left(\mathrm{kg} \cdot \mathrm{d}^{-1}\right)$ & 1.08 & 1.08 & 1.08 & - & \\
Final live weight $(\mathrm{kg})$ & 444 & 443 & 450 & 62 & $\mathrm{NS}$ \\
Average daily gain $\left(\mathrm{kg} \cdot \mathrm{d}^{-1}\right)$ & 1.05 & 1.03 & 1.09 & 0.21 & $\mathrm{NS}$ \\
Live weight gain per ha $\left(\mathrm{kg} \cdot \mathrm{ha}^{-1}\right)$ & $903 \mathrm{a}$ & $895 \mathrm{a}$ & $629 \mathrm{~b}$ & 87 & $* * *$ \\
Number of grazing days $\left(\mathrm{d} \cdot \mathrm{ha}^{-1}\right)$ & $870 \mathrm{a}$ & $870 \mathrm{a}$ & $580 \mathrm{~b}$ & 69 & $* * *$ \\
\hline
\end{tabular}

Means within a row with different superscripts differ significantly at $P<0.05$.

Table IV. Nitrogen balance per ha per year and efficiency of nitrogen utilisation in grazed pastures fertilised at $140(\mathrm{HN}), 93(\mathrm{MN})$ or $0(\mathrm{ON})$ $\mathrm{kg} \mathrm{N} \cdot \mathrm{ha}^{-1}$ and grazed at a stocking rate of respectively at 6,6 or 4 Belgian Blue bulls $\cdot \mathrm{ha}^{-1}$.

\begin{tabular}{lcccc}
\hline & \multicolumn{3}{c}{ Treatments } \\
\cline { 2 - 6 } HN MN ON \\
\hline Inputs (kg N) & 10 & 10 & 10 \\
- Rain fall & 140 & 93 & 3 \\
- Fertiliser & 56 & 64 & 54 \\
- Legume fixation & 16 & 16 & 10 \\
- Feedstuff & 222 & 183 & 78 \\
Total (kg N) & 28 & 28 & 20 \\
Outputs (kg N) & 193 & 155 & 58 \\
Balance $^{1}(\mathrm{~kg} N)$ & 13 & 15 & 26 \\
${\text { Apparent nitrogen efficiency }(\%)^{2}}^{2}$ & & & & \\
\hline Balance $^{1}=$ Inputs - Outputs. & & & &
\end{tabular}

finishing. The average daily gain was similar in the three groups $\sim 1 \mathrm{~kg} \cdot \mathrm{d}^{-1}$. During the indoor finishing, the average daily gain was significantly higher than during the grazing period $(P<0.001)$ and similar in the three groups at $1.32 \mathrm{~kg} \cdot \mathrm{d}^{-1}$. Such live weight gain was, however, significantly lower $(P<0.05)$ than that recorded in the FI group $\left(1.50 \mathrm{~kg} \cdot \mathrm{d}^{-1}\right)$. Intermediate data at $1.16 \mathrm{~kg} \cdot \mathrm{d}^{-1}$ were obtained when both periods were considered.

The total concentrate intake during the finishing period was calculated on a group basis. It was similar at $850 \mathrm{~kg}$ in the 3 groups of bulls previously grazed. It was significantly lower $(P<0.001)$ than $1361 \mathrm{~kg}$ recorded in the FI group. By contrast, there were no differences when feed intake was expressed on a daily basis. The feed conversion ratio was significantly in favour of the FI group at $5.77 \mathrm{~kg} \cdot \mathrm{kg}^{-1} \mathrm{vs}$. $6.97 \mathrm{~kg} \cdot \mathrm{kg}^{-1}(P<0.05)$ for the groups previously grazed.

The slaughter and carcass weights were similar between treatments. However the weights in the FI group tended to be lower compared to the animals grazed previously (548 kg vs. $569 \mathrm{~kg}$ for slaughter weight and 342 vs. $353 \mathrm{~kg}$ for carcass weight). The dressing percentage calculated as the ratio of carcass weight on slaughter weight was similar between treatments $(62 \%$; $P>0.05)$. The composition of the carcass (percentage of muscle and connective and adipose tissue) was equal between treatments (73\% and $13 \%$ respectively). The bone percentage was significantly lower in the FI group than in the MN and $\mathrm{ON}$ groups (12.8 vs. $13.5 \% ; P<0.05)$ but no significant difference in bone percentage was noted between the groups previously grazed (average of $13.3 \%$ ).

The chemical composition of meat was not affected by the treatments. The average crude protein and ether extract contents were 89.7 and $3.5 \%$ DM respectively (Tab. VI). The carcass temperatures and $\mathrm{pH}$ were similar in the four groups. Brightness 
Table V. Animal performance, slaughter and carcass characteristics of Belgian Blue bulls finished indoors after being initially grazed on pastures fertilised at $140(\mathrm{HN}), 93(\mathrm{MN})$ or $0(\mathrm{ON}) \mathrm{kg} \mathrm{N} \cdot \mathrm{ha}^{-1}$ and grazed at a stocking rate of 6,6 or 4 Belgian Blue bulls'ha ${ }^{-1}$ or fattened indoors (FI).

\begin{tabular}{|c|c|c|c|c|c|c|}
\hline & \multicolumn{6}{|c|}{ Treatment } \\
\hline & $\mathrm{HN}$ & $\overline{\mathrm{MN}}$ & $\mathrm{ON}$ & FI & RSD & $P$ \\
\hline Initial weight (kg) & 293 & 294 & 293 & - & 53 & NS \\
\hline Final grazing weight (kg) & 444 & 443 & 450 & - & 62 & NS \\
\hline Initial finishing weight (kg) & 447 & 442 & 449 & 312 & 64 & NS \\
\hline Final weight $(\mathrm{kg})$ & 575 & 565 & 575 & 553 & 58 & NS \\
\hline \multicolumn{7}{|l|}{ Duration (d) } \\
\hline Indoor fattening & $96 \mathrm{a}$ & $97 \mathrm{a}$ & $94 \mathrm{a}$ & $163 b$ & 22 & $* * *$ \\
\hline Grazing and indoor & 241 & 242 & 239 & - & 23 & NS \\
\hline \multicolumn{7}{|l|}{ Daily live weight gain $(\mathrm{kg})$} \\
\hline Pasture & 1.05 & 1.03 & 1.09 & - & 0.21 & \\
\hline Indoor & $1.32 \mathrm{a}$ & $1.28 \mathrm{a}$ & $1.35 \mathrm{a}$ & $1.50 \mathrm{~b}$ & 0.24 & $* * *$ \\
\hline Both periods & $1.16 \mathrm{a}$ & $1.13 \mathrm{a}$ & $1.18 \mathrm{a}$ & $1.50 \mathrm{~b}$ & 0.16 & $* *$ \\
\hline \multicolumn{7}{|l|}{ Fattening feed intake (kg) } \\
\hline Total & $854 a$ & $861 \mathrm{a}$ & $836 \mathrm{a}$ & $1361 b$ & 207 & $* * *$ \\
\hline Daily & 8.8 & 8.8 & 8.8 & 8.5 & 0.50 & NS \\
\hline Feed conversion ratio $\left(\mathrm{kg} \cdot \mathrm{kg}^{-1}\right)$ & $6.91 \mathrm{a}$ & $7.15 \mathrm{a}$ & $6.84 \mathrm{a}$ & $5.77 \mathrm{~b}$ & 1.38 & $*$ \\
\hline Total grazing and indoor feed intake $(\mathrm{kg})$ & 1002 & 1011 & 982 & 1364 & 221 & $*$ \\
\hline \multicolumn{7}{|l|}{ Slaughter } \\
\hline Slaughter weight (kg) & 575 & 561 & 572 & 548 & 58 & NS \\
\hline Carcass weight $(\mathrm{kg})$ & 357 & 349 & 352 & 342 & 39 & NS \\
\hline Dressing percentage $(\%)$ & 62.1 & 62.2 & 61.5 & 62.2 & 2.1 & NS \\
\hline \multicolumn{7}{|l|}{ Carcass } \\
\hline Muscle (\%) & 73.5 & 72.6 & 73.7 & 73.8 & 2.19 & NS \\
\hline Connective and adipose tissue (\%) & 13.6 & 13.9 & 12.8 & 13.4 & 1.85 & NS \\
\hline Bone $(\%)$ & $13.0 \mathrm{a}$ & $13.5 b$ & $13.5 b$ & $12.8 \mathrm{a}$ & 1.01 & $*$ \\
\hline
\end{tabular}

Means within a row with different superscripts differ significantly at $P<0.05$.

(L*) was significantly higher for the FI group compared to the $\mathrm{ON}, \mathrm{MN}$ and $\mathrm{HN}$ groups $(P<0.01)$. a* was the lowest in the FI group (17.0 vs. 18.3 for the MN group; $P<0.05)$. $\mathrm{b}^{*}$ was not affected by the treatments. The drip losses were similar, but the cooking losses were the lowest in the FI group (28.3 vs. 30.5 for the MN group; $P<0.05)$. The Warner Bratzler peak shear force was not different between the treatments.

The fatty acid composition of intramuscular fat of the HN and FI groups are shown in Table VII. The major fatty acids were C16:0 (26.5\%), C18:0 (19.3\%) and C18:1 (34.2\%). In the HN group, the proportions of $\mathrm{C} 18: 1$ and $\mathrm{C} 18: 3$ fatty acids were higher (36.4 vs. $31.9 \%, P>0.05,2.5$ vs. $1.5 \% ; P<0.05)$ than in the FI group.

\section{DISCUSSION}

\subsection{Vegetal aspects}

Average grass heights of $6.6 \mathrm{~cm} \mathrm{ob-}$ served in the plots with nitrogen fertiliser were in line with the data by Wright and Whyte [57] and Hodgson [25]. Grass production, measured in small plots protected 


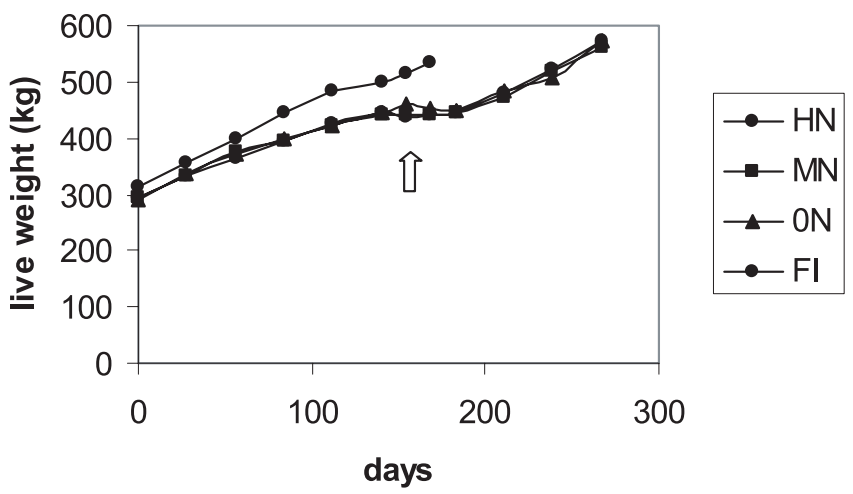

Figure 1. Live weight changes of Belgian Blue bulls finished indoors after being initially grazed on pastures fertilised at $140(\mathrm{HN}), 93(\mathrm{MN})$ or $0(\mathrm{ON}) \mathrm{kg} \mathrm{N} \cdot \mathrm{ha}^{-1}$ and grazed respectively at 6,6 or 4 Belgian Blue bulls $\cdot \mathrm{ha}^{-1}$ or bulls fattened indoors (FI). The arrow indicates the beginning of the indoor finishing for the bulls previously grazed.

Table VI. Meat composition and quality parameters of Belgian Blue bulls finished indoors after being initially grazed on pastures fertilised at $140(\mathrm{HN}), 93(\mathrm{MN})$ or $0(\mathrm{ON}) \mathrm{kg} \mathrm{N} \cdot \mathrm{ha}^{-1}$ and grazed at a stocking rate of 6,6 or 4 Belgian Blue bulls $\cdot \mathrm{ha}^{-1}$ or fattened indoors (FI).

\begin{tabular}{lcccccc}
\hline & \multicolumn{7}{c}{ Treatment } \\
\cline { 2 - 7 } & HN & MN & ON & FI & RSD & P \\
\hline Chemical composition & & & & & & \\
Dry matter (\%) & 24.3 & 23.9 & 23.8 & 24.2 & 0.9 & $\mathrm{NS}$ \\
Ash (\% DM) & 5.0 & 4.7 & 4.7 & 4.7 & 0.4 & $\mathrm{NS}$ \\
Crude protein (\% DM) & 89.6 & 89.6 & 89.3 & 90.1 & 0.5 & $\mathrm{NS}$ \\
Ether extract (\% DM) & 3.6 & 3.4 & 3.6 & 3.3 & 0.3 & $\mathrm{NS}$ \\
Meat characteristics & & & & & & \\
pH after 4 h & 6.0 & 6.0 & 6.1 & 5.9 & 0.1 & $\mathrm{NS}$ \\
pH after 48 h & 5.6 & 5.5 & 5.5 & 5.5 & 0 & $\mathrm{NS}$ \\
$\mathrm{T}\left({ }^{\circ} \mathrm{C}\right)$ after 4 h & 27.0 & 27.1 & 26.4 & 28.9 & 0.1 & $\mathrm{NS}$ \\
Meat colour & & & & & & \\
L* & $42.5 \mathrm{a}$ & $42.5 \mathrm{a}$ & $41.6 \mathrm{a}$ & $44.2 \mathrm{~b}$ & 3.0 & $* *$ \\
$\mathrm{a} *$ & $17.2 \mathrm{ab}$ & $18.3 \mathrm{~b}$ & $18.0 \mathrm{ab}$ & $17.0 \mathrm{a}$ & 1.8 & $*$ \\
$\mathrm{~b} *$ & 16.9 & 17.5 & 16.9 & 17.4 & 1.7 & $\mathrm{NS}$ \\
Drip (\%) & 6.0 & 5.6 & 5.7 & 5.6 & 1.2 & $\mathrm{NS}$ \\
Cooking losses $(\%)$ & $29.4 \mathrm{ab}$ & $30.5 \mathrm{~b}$ & $30.2 \mathrm{ab}$ & $28.3 \mathrm{a}$ & 3.7 & $*$ \\
Peak shear force $(\mathrm{N})$ & 37.4 & 38.8 & 39.5 & 37.4 & 9.2 & $\mathrm{NS}$ \\
\hline
\end{tabular}

Means within a row with different superscripts differ significantly at $P<0.05$. 
Table VII. Fatty acid composition (molar percentage) in intramuscular fat of Belgian Blue bulls finished indoors after being initially grazed on pastures fertilised at $140 \mathrm{~kg} \mathrm{~N} \cdot \mathrm{ha}^{-1}$ and grazed at a stocking rate of 6 Belgian Blue bulls $\cdot \mathrm{ha}^{-1}(\mathrm{HN})$ or fattened indoors (FI).

\begin{tabular}{lcccc}
\hline & \multicolumn{4}{c}{ Treatment } \\
\cline { 2 - 5 } & HN & FI & RSD & P \\
\hline C14:0 & 1.7 & 2.0 & 1.0 & NS \\
C16:0 & 25.7 & 27.2 & 4.4 & NS \\
C16:1 & 1.2 & 1.5 & 0.7 & NS \\
C18:0 & 18.8 & 19.8 & 3.1 & NS \\
C18:1 & 36.4 & 31.9 & 6.0 & NS \\
C18:2 & 13.9 & 15.7 & 5.8 & NS \\
C18:3 & $2.5 b$ & $1.5 \mathrm{a}$ & 0.7 & $*$ \\
SFA & 46.1 & 48.5 & 4.0 & NS \\
MUFA & 37.6 & 33.0 & 6.6 & NS \\
PUFA & 16.3 & 18.6 & 7.2 & NS \\
UFA/SFA & 1.17 & 1.08 & 0.18 & NS \\
PUFA/SFA & 0.35 & 0.40 & 0.17 & NS \\
\hline
\end{tabular}

Means within a row with different superscripts differ significantly at $P<0.05$.

from grazing, increased with the level of fertilisation as is commonly observed [8]. The response to nitrogen fertilisation in terms of grass yield was $21 \mathrm{~kg} \mathrm{DM} \cdot \mathrm{kg}^{-1}$ between $\mathrm{ON}$ and $\mathrm{MN}$ and $6.5 \mathrm{~kg} \mathrm{DM} \cdot \mathrm{kg}^{-1}$ $\mathrm{N}$ between $\mathrm{MN}$ and $\mathrm{HN}$. The lower primary production in the ON group implied that the stocking rate had to be modified. According to Holmes [26] and Prins [42] respectively, responses varying between 15 to $7.5 \mathrm{~kg}$ could be expected with nitrogen application of 200 to $400 \mathrm{~kg} \cdot \mathrm{ha}^{-1}$. With a lower rate of nitrogen application $\left(80 \mathrm{~kg} \mathrm{~N} \cdot \mathrm{ha}^{-1}\right)$, Frame [18] reported responses of $20 \mathrm{~kg}$ DM per $\mathrm{kg} \mathrm{N}$ while Whitehead [53] reported a response from 20-30 kg DM. $\mathrm{kg}^{-1} \mathrm{~N}$ until application of 250-400 kg.ha ${ }^{-1}$. Lambert [32] reported that response for spring application of $\mathrm{N}$ in pastures of rye grass was maximum up to $80 \mathrm{~kg} \mathrm{~N} \cdot \mathrm{ha}^{-1}$ and was much lower with an application above $140 \mathrm{~kg} \mathrm{~N} \cdot \mathrm{ha}^{-1}$. In the present study, the additional production on HN compared to MN was low. It appeared thus that the maximal response was reached in $\mathrm{MN}$ plots.

The reduction of white clover proportion in pastures fertilised with nitrogen is currently described and is associated with a better use of mineral nitrogen by the gramineae and a reduction of nitrogen fixation by the clover [17]. The botanical composition did not differ to a large extent between $\mathrm{ON}$ and MN. This lack of effect could be explained by a lower grass height and a higher stocking rate in the MN group compared with ON. At higher stocking rates, the development and the branching of clover were favoured [17]. The fertilisation effects on the clover were weaker when defoliation of the pasture is frequent [19].

The dry matter content of grass was not affected by the treatments. The opposite was noted by Demarquilly [9] in which nitrogen fertilisation reduced the dry matter content. The lack of difference observed in the present study was previously reported in another experiment in which dairy cows were rotationally grazed according to a similar experimental design [10].

There were no differences between treatments for the contents of crude protein, soluble nitrogen, soluble non protein nitrogen, soluble protein nitrogen, ammonia and nitrates. It is usually reported that nitrogen fertilisation increases the crude protein content of grass [41]. The larger proportion of white clover in the ON group as compared to the HN group could explain the lack of significant differences in terms of crude protein content even if nitrogen fertilisation was higher in the other group [31].

The potassium and phosphorus contents were in the range of data reported by Hemingway [24]. In the HN group, the smaller calcium contents were associated with the reduction of white clover when nitrogen fertiliser was increased [24]. The increase in sodium content with an increase 
in mineral nitrogen fertiliser was reported by Reid and Strachan [45]. On the whole, it appeared that the different managements in the pastures grazed by the growing bulls induced only rather small differences in terms of sward characteristics.

\subsection{Performances of grazed bulls}

The increase of nitrogen fertilisation in the $\mathrm{HN}$ and MN groups allowed an improvement of the number of grazing days. Micol et al. [37] reported an average increase of 355 grazing days per ha between two nitrogen fertilizsation levels (33 vs. $311 \mathrm{~kg} \mathrm{~N} \cdot \mathrm{ha}^{-1}$ ) and an improvement of 235 grazing days per ha by an increase of the stocking rate from 4.9 to 6.3 animals $\cdot \mathrm{ha}^{-1}$. Steen [49] also reported a significant improvement in the number of grazing days with the increase of the stocking rate.

The average daily gains observed in the present trial were in agreement with those reported by Dufrasne et al. [12] and Raskin et al. [44] with Belgian Blue cattle at grass. The effect of the stocking rate is normally inversely related to the average daily gain if there is no increase in the grass availability obtained, for example, by nitrogen fertilisation [46]. In the present study, however, the one third reduction in nitrogen fertiliser did not affect the individual performance, with grass height not being reduced by the reduction in nitrogen fertiliser. Such an observation implied that the bulls of the MN group were offered a similar amount of grass as the animals of the HN groups. Without nitrogen fertiliser, and with an adapted stocking rate, the individual animal performances were similar to those in the more intensively managed groups. Such results were in line with those of Grenet et al. [21] and Keane and Allen [31] who compared two intensification levels with grazing bulls and reported similar live weight gains in the groups.

\subsection{Nitrogen balance}

The amounts of nitrogen fixed by the legumes was similar to that reported by Orr et al. [40]; it varied from 30 to $60 \mathrm{~kg}$ fixed $\mathrm{N} \cdot \mathrm{ha}^{-1} \cdot$ year $^{-1}$, but according to Frame [17], the amount of fixed nitrogen could be as high as $280 \mathrm{~kg}$ fixed $\mathrm{N} \cdot \mathrm{ha}^{-1}$. The low nitrogen output in terms of meat in the ON group was the result of the lower stocking rate in that group. Such results were in agreement with those of Farruggia et al. [15] and Stevens [50]. The nitrogen not exported as animal products was either stored in the soil or lost as leaching or volatilisation.

The nitrogen balances were comparable to those published by Farruggia et al. [15], who reported positive nitrogen balances in pastures grazed by growing cattle. Usually, nitrogen balance is proportional to the inputs of the system, and particularly to the amounts of nitrogen fertilisers. However, excessive positive nitrogen balances along with nitrogen restitutions in the pasture are influenced mainly by the number of grazing days $[15,58]$.

The nitrogen utilisation efficiency was low as compared with dairy cow systems and was in agreement with data reported in the literature $[30,50]$. The system with no nitrogen induced an improvement in efficiency. Such results agreed with those reported by Stevens [50] who observed a reduction of utilisation efficiency from $14.8 \%$ to $9.1 \%$ when nitrogen inputs increased from 108 to $308 \mathrm{~kg} \mathrm{~N} \cdot \mathrm{ha}^{-1}$.

\subsection{Fattening performance}

The live weight gains during the finishing period of the bulls which were previously grazed were higher than during the grazing period. Such a compensatory growth with grazed cattle when they were finished indoors has already been reported by Dufrasne et al. [12] and Schlegel 
et al. [46]. The animal performance for the overall period was to some extent lower than that of the FI group. The main differences were a longer fattening period, lower daily live weight gain and larger total feed intake. Schwarz et al. [47] also observed higher average daily live weight gains and a reduction of the total finishing period in heifers fattened indoors compared to animals fattened in pasture $\left(1 \mathrm{~kg} \cdot \mathrm{d}^{-1}\right.$ vs. $\left.0.66 \mathrm{~kg} \cdot \mathrm{d}^{-1}\right)$. Myers et al. [39] noted lower daily live weight gains for growing bulls in pasture compared to bulls fattened indoors $\left(0.48 \mathrm{vs} .1 .33 \mathrm{~kg} \cdot \mathrm{d}^{-1}\right.$ respectively), but the daily live weight gains during the indoor finishing were higher for the groups which were grazed (1.40 vs. $\left.1.28 \mathrm{~kg} \cdot \mathrm{d}^{-1}\right)$. In the present study, compensation was partial since the animals that grazed did not reach the live weight of the FI animals at the same age. Three reasons may help explain the lower performance of bulls which grazed [12]. First, the bulls grazed and then finished indoors had to adapt twice to new regimes while only one transition period was necessary for the FI group. During these adaptation periods, the live weight gain was low. Secondly, the energy requirements for walking with cattle at grass are, according to ARC [1], proportionately about $15 \%$ of the maintenance requirements. Such expenses would be considerably lower for housed animals. Finally, grass was not always available in sufficient quantity and quality owing to climate and rainfall. By contrast, concentrate food was offered ad libitum. The conditions in terms of management, environment and diet availability and type were thus more favourable for the FI group. Since the indoor period was shortened for groups that were grazed, the grazing period reduced the concentrate requirement by $505 \mathrm{~kg}$, but increased feed conversion efficiency. The grazing bulls ate $157 \mathrm{~kg}$ of concentrate but this concentrate was cheaper than the concentrate offered during the fattening. A higher feed con- version ratio was also observed by Myers et al. [39] and Mader et al. [34] for indoor animals. Feed conversion ratios of the three grazed groups did not differ significantly as observed by Schlegel et al. [46] with bulls which previously grazed at two stocking rates on an alfalfa pasture.

\subsection{Slaughter performance and meat quality}

Slaughter and carcass weights, dressing percentage and composition of carcass were similar between the treatment groups, the slaughter being decided according to the finishing state. The tendency for a lower slaughter weight in the FI group suggested that the fattening was faster in relation with higher average daily gains. The contents of ether extract and crude protein in this study were in agreement with those published by Van Eenaeme et al. [52] for Belgian Blue bulls, with one of the characteristics of this breed being the production of a very lean meat. The contents of dry matter, crude protein and ether extract were not different between treatments. Similarly, with bulls finished on pasture with two levels of intensification, Keane and Allen [31] did not find any effects of nitrogen fertilisation or stocking rate on the chemical composition of the meat. The results found in this study have to be linked to the common finishing period in which the diet and the housing conditions were the same. This common finishing period probably reduced any potential differences due to the grazing period.

The decline in carcass $\mathrm{pH}$ is due to the normal decrease in glycogen reserves, no significant difference being observed between the treatments. Similarly, Ender et al. [14] did not observe differences in meat $\mathrm{pH}$ of bulls finished indoors, on pasture or indoors after a grazing period. Keane and Allen [31] did not report differences in meat $\mathrm{pH}$ of bulls finished 
in pasture with different stocking rates. However, Schwarz et al. [47] observed a reduction of the $\mathrm{pH}$ values 48 hours postmortem in heifers fattened indoors compared to finishing on pastures: the values of the group previously grazed and finished indoors were intermediate. The meat in the FI group was the brightest as indicated by a significantly higher $\mathrm{L}^{*}$ and was less red (lowest $\mathrm{a}^{*}$ ). There was no difference for $\mathrm{b}^{*}$. Significant correlations were reported between brightness $\left(\mathrm{L}^{*}\right)$ and fattening duration $(\mathrm{r}=21.5 \% ; P<0.05)$ and between the slaughter weight and the red colour $\left(\mathrm{a}^{*}\right)$ $(\mathrm{r}=33.6 \% ; P<0.05)$. Priolo et al. [43] and Schwarz et al. [47] also observed higher L* values in the meat of bulls fattened indoors compared to the animals finished on pastures. These latter authors associated the meat brightness with animal age, the animals that were grazed being older due to a longer fattening period. This may also explain the small differences noted in this study. Furthermore, it was probable that pigments such as carotene were responsible for the increase of darkness as shown by Forrest [16]. Schwarz et al. [47] found that the fat of animals that were grazed was more yellow due to the carotene pigments, with this effect being less important during the indoor finishing period. In this experiment, the identical diet offered during the indoor finishing period probably also levelled the differences.

The drip losses did not differ between treatments, the cooking losses being, however, lower in the FI group. Dufrasne et al. [12] and Schwarz et al. [47] observed similar results but Myers et al. [39] and Keane and Allen [31] did not note any differences between animals which were fattened indoors or grazed. The Warner Bratzler peak shear force of Longissimus Thoracis muscle at $38.3 \mathrm{~N}$ observed in this experiment was in line with the results published by Clinquart et al. [4] for bulls of the Belgian Blue breed. In this experiment, the Warner Bratzler peak shear force did not differ between the treatments. These results were in agreement with those published by Schwarz et al. [47], Ender et al. [14] and Keane and Allen [31].

The composition of the intramuscular fatty acids followed the same pattern as that reported in the review of Wood et al. [54] for marketed meat. The present C18:1 concentration tended to be higher for bulls which were grazed. A similar effect was also observed by Mandell et al. [35] with steers finished indoors on a cereal diet after a growing period on grass silage compared to a control group fattened indoors on a cereal diet. The slight reduction of the concentration of C18:2 and the significant increase of the concentration in C18:3 in the intramuscular fat of bulls previously grazed were in agreement with the observations of Wood et al. [56], Marmer et al. [36] and Hornick et al. [27]. The determination of the concentration in C18:3 could be used to trace the fattening management when a grazing period is included. The duration of the finishing period, during which all bulls received an identical diet, was probably sufficiently short so that the carry over effect of grazing was still present in order to influence the composition in fatty acids of the meat, with grass being high in linolenic acid [55]. The ratio of unsaturated fatty acids/saturated fatty acids in meat was increased from 1.08 in the FI group to 1.17 in the $\mathrm{HN}$ group; such a reduction is of interest for human health [13].

\section{CONCLUSION}

A $33 \%$ reduction in nitrogen fertiliser at an unchanged stocking rate did not affect either the grass characteristics or animal performances. It may be concluded that applying 27 compared to $40 \mathrm{~kg} \mathrm{~N} \cdot \mathrm{ha}^{-1}$ at each spreading permitted nitrogen saving and tended to increase nitrogen utilisation efficiency without any effect on animal performances. 
A grazing system with no nitrogen fertiliser resulted in similar individual animal performances as high as those in more intensive systems if the stocking rate is adapted. Such a management appeared more like an extensive system allowing a more environmentally friendly production with reduced excess nitrogen.

The inclusion of a grazing period before an indoor finishing induced lower daily live weight gains and a longer fattening period as compared to animals fattened indoors. The total live weight gain in pasture was high at $150 \mathrm{~kg}$ per animal with a $26 \%$ reduction in concentrate consumption. Furthermore, during the grazing period, a reduction or a suppression of nitrogen fertilisation can also be considered. This alternative to an indoor fattening thus fully agrees with the current policy of the extensification of bovine production. The inclusion of a grazing period changed the colour of meat, but not tenderness. The higher content of C18:3 n-3 and lower SFA proportions could be of interest for human health and traceability of the diet.

\section{REFERENCES}

[1] Agricultural Research Council, The nutrient requirements of ruminant livestock, Commonwealth Agricultural Bureaux, Farnham Royal, Slough, 1990.

[2] Andries A., L'appréciation dans la pratique de la valeur agricole des herbages, par l'examen de leur composition botanique, Rev. Agric. Brussels 12 (1950) 15-19.

[3] AOAC, Official methods of analysis (12th ed.), Association of Official Analytical Chemists, H. Horwitz (Ed.), Washington DC, 1975 .

[4] Clinquart A., Van Eenaeme C., Van Vooren T., Van Hoof J., Hornick J.L., Istasse L., Meat quality in relation to breed (Belgian Blue vs. Holstein) and conformation (Double muscled vs. Dual purpose type), Sci. Alim. 14 (1994) 403-409.

[5] Dagnelie P., Théorie et méthodes statistiques, Presses Agronomiques de Gembloux, Gembloux, Belgique, 1975.
[6] De Campeneere S., Fiems L.O., De Pape M., Vanacker J.M., Boucqué C.V., Compositional data on Belgian Blue doublemuscled bulls, Anim. Res. 50 (2001) 43-55.

[7] Decau M.L., Delaby L., Roche B., AzoPât : une description quantifiée des flux annuels d'azote en prairie pâturée par les vaches laitières. II - Le flux du système sol-plante, Fourrages 151 (1997) 297-312.

[8] Delaby L., Peyraud J.L., Effet d'une réduction simultanée de la fertilisation azotée et du chargement sur les performances des vaches laitières et la valorisation du pâturage, Ann. Zootech. 47 (1998) 17-39.

[9] Demarquilly C., Fertilisation et qualité du fourrage, Fourrages 69 (1977) 61-84.

[10] Dieguez Cameroni F., Hornick J.-L., De Behr V., Istasse L., Dufrasne I., Réduction et absence de fertilisation azotée sur des prairies pâturées par des vaches laitières, Anim. Res. 50 (2001) 299-314.

[11] Dufrasne I., Gielen M., Limbourg P., Brundseaux C., Istasse L., Production bovine allaitante en Belgique : effets de l'intensification et de la complémentation des veaux au pâturage, Fourrages 141 (1995) 91-104.

[12] Dufrasne I., Gielen M., Limbourg P., Van Eenaeme C., Istasse L., Effect of a grazing period on performance of finishing bulls: comparison with an indoor finishing system, Anim. Sci. 60 (1995) 75-80.

[13] Dupont J., White P.J., Feldman E.B., Saturated and hydrogenated fats in food in relation to health, J. Am. Coll. Nutr. 10 (1991) 577-592.

[14] Ender K., Papstein H.J., Nurnberg K., Wegner J., Muscle and fat related characteristics of grazing steers and lambs in extensive systems, in: Fiems L.O., De Campeneere S. (Eds.), Effects of extensification on animal performance, carcass composition and product quality, Proceedings of a workshop, May 16-17, Melle-Gontrode, Belgium, 1997, pp. 229-237.

[15] Farruggia A., Decau M.L., Vertes F., Delaby L., En prairie, la balance azotée à l'échelle de la parcelle, Fourrages 151 (1997) 281-295.

[16] Forrest R.J., A comparison of the growth and carcass characteristics of steers reared on pasture and finished for varying periods on corn or grass silage, Can J. Anim. Sci. 62 (1982) 1079-1088.

[17] Frame J., Improved grassland management, Farming Press Books, Ipswich, UK, 1992. 
[18] Frame J., The effect of strategic fertilizer nitrogen and date of primary harvest on the productivity of a perennial ryegrass/white clover sward, Grass Forage Sci. 42 (1987) $33-42$.

[19] Frame J., Boyd A.G., The effect of fertilizer nitrogen rate, white clover variety and closeness of cutting on herbage productivity from perennial ryegrass/white clover swards, Grass Forage Sci. 42 (1987) 85-96.

[20] Gielen M., Dufrasne I., Limbourg P., Diez M., Istasse L., Effects of stocking rate on animal performance and profit with grazing bulls finished indoors, 44th Annual Meeting of the European Association for Animal Production, 1993, p. 110.

[21] Grenet N., Micol D., Haurez P., Dozias D., Pflimlin A., Production of high quality beef under extensive conditions in France, in: Fiems L.O., De Campeneere S. (Eds.), Effects of extensification on animal performance, carcass composition and product quality, Proceedings of a workshop, May 16-17, Melle-Gontrode, Belgium, 1997, pp. $248-267$.

[22] Hanset R., Bienfait J.M., Jandrin M., Nicks B., Leroy P., L'intérêt d'un segment monocostal dans l'appréciation des carcasses des jeunes taureaux, Ann. Méd. Vét. 122 (1978) 37-44.

[23] Hanset R., Detal G., Michaux C., The Belgian breed in pure and crossbreeding: growth and carcass characteristics, Rev. Agr. 42 (1989) 255-264.

[24] Hemingway R.G., The effect of changing patterns of fertilizer applications on the major mineral composition of herbage in relation to the requirements of cattle: a 50-year review, Anim. Sci. 69 (1999) 1-18.

[25] Hodgson J., Grazing Management, in: Whittemore C., Simpson K. (Eds.), Longman Group, UK, 1990.

[26] Holmes W., The use of nitrogen in the management of pasture for cattle, Herbage Abstracts 38 (1968) 265-276.

[27] Hornick J.L., Raskin P., Clinquart A., Dufrasne I., Van Eenaeme C., Istasse L., Compensatory growth in Belgian Blue bulls previously grazed at two stocking rates: animal performance and meat characteristics, Anim. Sci. 67 (1998) 427-434.

[28] INRA, Alimentation des ruminants, Valeur nutritive des aliments, INRA Publications, Versailles, France, 1980.
[29] INS - Institut National de Statistiques, Statistiques agricoles, Ministère des Affaires Économiques, 1999.

[30] Jarvis S.C., Hatch D.J., Roberts D.H., The effects of grassland management on nitrogen losses from grazed swards through ammonia volatilisation: The relationship to excretal $\mathrm{N}$ returns from cattle, J. Agr. Sci. Camb. 112 (1989) 205-216.

[31] Keane M.G., Allen P., Effects of pasture fertiliser $\mathrm{N}$ level on herbage composition, animal performance and on carcass and meat quality traits, Livest. Prod. Sci. 61 (1999) 233-244.

[32] Lambert R., Influence du climat et de la disponibilité en azote sur la croissance printanière du ray-grass anglais, Ph.D. Thesis, Université Catholique Louvain, Belgium, $90 \mathrm{p}$

[33] Leach K.A., Bax J.A., Efficiency of nitrogen use in dairy systems, in: Corrall A.J. (Ed.), Proceedings of the 33th Occasional Symposium of British Grassland Society, Oxfordshire, UK, 1999, pp. 69-74.

[34] Mader T.L., Turgeon O.A., Klopfenstein T.J., Brink D.R., Oltjen R.R., Effects of previous nutrition, feedlot regimen and protein level on feedlot performance of beef cattle, J. Anim. Sci. 67 (1989) 318-328.

[35] Mandell I.B., Buchanan-Smith J.G., Campbell C.P., Effects of forage vs. grain feeding on carcass characteristics, fatty acid composition and beef quality in Limousincross steers when time on feed is controlled, J. Anim. Sci. 76 (1998) 2619-2630.

[36] Marmer W.N., Maxwell R.J., Williams J.E., Effects of dietary regimen and tissue site on bovine fatty acid profiles, J. Anim. Sci. 59 (1984) 109-121.

[37] Micol D., Peccatte J.R., Muller A., Croissance des bovins en relation avec différentes modalités d'exploitation du pâturage, Fourrages, Supplément des Journées AFPF, Paris, France, 1992, pp. 67-68.

[38] Minitab, Minitab reference manual, Valley Forge Data Tech. Industries, 1989, 349 p.

[39] Myers S.E., Faulkner D.B., Nash T.G., Berger L.L., Parrett D.F., Mc Keith F.K., Performance and carcass traits of earlyweaned steers receiving either a pasture growing period or a finishing diet at weaning, J. Anim. Sci. 77 (1999) 311-322.

[40] Orr R.J., Parsons A.J., Penning P.D., Sward composition, animal performance and the potential production of grass/white clover 
swards continuously stocked with sheep, Grass Forage Sci. 45 (1990) 325-336.

[41] Peyraud J.L., Astigarraga L., Review of the effect of nitrogen fertilization on the chemical composition, intake, digestion and nutritive value of fresh herbage: consequences on animal nutrition and $\mathrm{N}$ balance, Anim. Feed Sci. Tech. 72 (1998) 235-259.

[42] Prins W.H., Limits to nitrogen fertilizer on grassland, Neth. J. Agr. Sci. 32 (1984) 319321 .

[43] Priolo A., Micol D., Agabriel J., Effets d'une alimentation à base d'herbe sur la couleur et la flaveur des viandes bovines, Renc. Rech. Rumin. 7 (2000) 267.

[44] Raskin P., Clinquart A., Dufrasne I., Ledent A., Istasse L., Less intensive meat production with belgian blue bulls: interest of a grazing period and different levels of nitrogen fertilizer, in: Fiems L.O., De Campeneere S. (Eds.), Effects of extensification on animal performance, carcass composition and product quality, Proceedings of a workshop, May 16-17, Melle-Gontrode, Belgium, 1997, pp. 102-107.

[45] Reid D., Strachan H., The effects of a wide range of nitrogen rates on some chemical constituents of the herbage from perennial ryegrass swards with and without white clover, J. Agr. Sci. Camb. 83 (1974) 393401.

[46] Schlegel M.L., Wachenheim C.J., Benson M.E., Black J.R., Moline W.J., Ritchie H.D., Schwab G.D., Rust S.R., Grazing methods and stocking rates for direct-seed alfalfa pastures: I. Plant productivity and animal performance, J. Anim. Sci. 78 (2000) 2192-2201.

[47] Schwarz F.J., Augustini C., Kirchgessner M., Effect of grazing or indoor feeding on animal performance and carcass and meat quality of Simmental or Angus $x$ Simmental heifers, in: Fiems L.O., De Campeneere S. (Eds.), Effects of extensification on animal performance, carcass composition and product quality, Proceedings of a workshop, May 16-17, Melle-Gontrode, Belgium, 1997, pp. 238-247.

[48] Simpson J.R., Stobbs T.H., Nitrogen supply and animal production from pastures, in: Morley (Ed.), Grazing Animals, Elsevier, Amsterdam, 1981, pp. 261-287.

[49] Steen R.W.J., A comparison of pasture grazing and storage feeding, and the effect of sward surface height and concentrate supplementation form 5 to 10 months of age on the lifetime performance and carcass composition of bulls, Anim. Prod. 58 (1994) 209219.
[50] Stevens R.J., Losses to water and air, in: Corral A. (Ed.), Accounting for nutrients: a challenge for grassland farmers in the 21 st century, Occasional Symposium No. 33, British Grassland Society, Oxfordshire, UK, 1999.

[51] Ter Meulen V.U., Nordbeck H., Molnar S., Untersuchungen zur Morphologie und Physiologie des perirenalen Fettgewebes beim Kalb und der Einfluss der Umgebungstemperatur auf seine Funktion. 2. Mitteilung. Methodik und Vesuchsergebnisse (Versuch I und II), Z. Tierphysiologie, Tierernärhung und Futtermittelkunde 35 (1975) 144-163.

[52] Van Eenaeme C., Minet V., Raskin P., Dufrasne I., Clinquart A., Hornick J.L., Diez M., Mayombo P., Baldwin P., Istasse L., Technical data on Belgian Blue double muscled bulls, in: Ministry of Small Entreprises, Traders and Agriculture, Recherche and Development, Ministry of Région Wallonne, General Directorate of Agriculture, University of Liège, Faculty of Veterinary Medicine, Nutrition (Eds.), Belgian Blue bulls. Their management for growing and finishing. An assessment of their performance and of carcass and meat quality, Presses de la Faculté de Médecine Vétérinaire de l'Université de Liège, Liège, 1997, pp. 23-40

[53] Whitehead D.C., Grassland nitrogen, CAB International, Wallingford, 1955, p. 397.

[54] Wood J.D., Enser M., Factors influencing fatty acids in meat and the role of antioxidants improving meat quality, Brit. J. Nutr. 78 (1997) S49-S60.

[55] Wood J.D., Enser M., Fisher A.V., Nute G.R., Richardson R.I., Sheard P.R., Manipulating meat quality and composition, Proc. Nutr. Soc. 58 (1999) 363-370.

[56] Wood J.D., Fisher A.V., Carcass and meat quality: definitions and measurements, in: Fiems L.O., De Campeneere S. (Eds.), Effects of extensification on animal performance, carcass composition and product quality, Proceedings of a workshop, May 1617, Melle-Gontrode, Belgium, 1997, pp. 3038.

[57] Wright I.A., Whyte T.K., Effects of sward surface heights on the performance of continuously stocked spring calving beef cows and their calves, Grass Forage Sci. 44 (1989) 259-266.

[58] Wulf D.M., Wise J.W., Measuring muscle color on beef carcasses using the $\mathrm{L}^{*} \mathrm{a} * \mathrm{~b}$ * color space, J. Anim. Sci. 77 (1999) 2418 2427. 